\title{
AN INVESTIGATION ON CURRENT GREEN DESIGN PRACTICES TOWARDS NET-ZERO ENERGY BUILDINGS (NZEBS) APPLICATION IN MALAYSIA HEALTHCARE PROJECTS
}

\author{
Roy Hazli Bin Abdellah ${ }^{1}$, Md Asrul Nasid Bin Masrom², Goh Kai Chen ${ }^{3}$, Sulzakimin Bin Mohamed ${ }^{4}$, \\ Norpadzlihatun Binti Manap ${ }^{5}$ \\ 1,2,3,4,5 Department of Construction Management, Faculty of Technology Management and Business, \\ Universiti Tun Hussein Onn Malaysia \\ *Corresponding E-mail: hazliroy@gmail.com
}

\begin{abstract}
These days, the topic on the sustainable building has become one of the most important concerns in the academic studies, construction industries, as well as governmental agencies. Sustainability in the building sector has raised the attention towards a new concept called net-zero energy buildings (NZEBs). With regards to the development of Malaysia's buildings sectors, the government has realised the undesirable effects of inefficient of energy usage by demonstrating their efforts in Construction Industry Transformation Programme (CITP) 2016-2020. Commonly, healthcare buildings are among the greatest energy consumers of any institution and the extensive use of various medical equipment, mechanical ventilation of this building has caused a high level of carbon emission. Hence, by concentrating on these issues, NZEBs become an important concept to be implemented in healthcare buildings. However, the awareness of NZEBs in Malaysia is still low and the construction industry in Malaysia still unaware of NZEBs. This paper aims to investigate the current design practices of healthcare buildings in Malaysia as well as the architect's understanding of NZEBs through preliminary investigation among architects. Literature was reviewed and pilot studies by using semi-structured interviews were conducted. The results uncover that some green practices related to the design practices in healthcare buildings has been carried out and some of these practices are similar to the NZEBs design practices even though the term of 'NZEBs' is not being used. It is predicted that the paper will provide a basic knowledge for future research in NZEBs for healthcare buildings, challenges of NZEBs implementation and designing NZEBs for healthcare buildings in Malaysia.
\end{abstract}

Keywords: Net zero energy buildings, Healthcare building, Current green design practices, Malaysia DOI: https://doi.org/10.30880/jtmb.2018.05.03.007

Received: October 16, 2018

Accepted: December 04, 2018

Published: December 15, 2018

\subsection{Introduction}

In recent years, the issue of the high level of energy consumption and carbon emission is the basis for the introduction of net-zero energy buildings (NZEBs) concept, and this concept has received a great attention by most countries. By having an increasing concern in environmental issues, European Union Parliament are gradually working towards a regulation that encourage the improvement of energy consumption as well as to reduce the level of carbon emission through the recast of the EU Directive on Energy Performance of Buildings (EPBD) in which all new buildings to be "nearly Zero-Energy" Buildings by 2020 (Recast, 2010). NZEBs concept is developed to represents a zero or low energy building that using renewable energy systems installed to meet the buildings energy consumption demands (Torcellini et al., 2010). Apart from that, Patiño et al., (2016) stated that NZEBs are buildings that achieve the benchmark efficiency by pursuing or outperforming a list of technical requisites. Therefore, NZEBs can represent buildings that utilise the renewable energy technologies and able enable to develop a network of clean domestic energy assets. 
The application of NZEBs concept in healthcare building is crucial because it perceived to be as the main part for the progression towards sustainability. Healthcare buildings require unique energy requirements and these kinds of buildings are complex with many people vulnerable to environmental conditions (Morgenstern et al., 2016). Besides that, hospitals itself, with its variety of building services, disposals of waste in large quantities, a wide range of equipment and machinery use and another addition of energy consumption, contribute to the environmental issue (Nawawi et al., 2013) Significantly, global warming is a major risk facing mankind. The concentration of $\mathrm{CO}^{2}$ in the atmosphere is increasing year on year, which enhances the natural greenhouse effect and warms the planet (Anderson, Hawkins \& Jones, 2016). According to the Intergovernmental Panel on Climate Change (IPCC), the temperature increase during the twenty-first century will be between 1.0 and 3.7 ${ }^{\circ} \mathrm{C}$, depending on the future emissions of greenhouse gases (Church et al., 2013).

Other than that, Malaysia has awakened by the fire incident at Hospital Sultanah Aminah, Johor Bahru that claimed the lives of six people in 2016 (Bernama, 2016). The causes of the fire incident as reported by News Strait Times involve technical issues like sparks from capacitor ceiling lights (Rizalman, 2016). Even though there are several other possible causes of electrical fire in a building, it is important to realise that overloading is a notable physical mechanism of electrical fire (Lee, Chow \& Hung, 2016). Overloading is where the electrical circuit or devices at high temperature might ignite itself and surrounding combustibles to cause a fire when the flowing current exceeds the maximum current carrying capacity (Wang et al., 2013). Based on the issue pointed out, the application of energy efficient systems is overlooked. Energy efficiency measures able to increase the level of productivity as well as to reduce the energy needed and increase the output whilst keeping energy consumption.

Therefore, the aim of this paper is to present findings on the current green design practices of healthcare buildings in Malaysia as well as the architect's understanding of NZEBs. Literature finds that there are various ways to design NZEBs, thus the focus is to identify which of the current green design practices for healthcare in Malaysia that are similar to NZEBs design strategies. This paper expects to give an understanding of NZEBs concept in Malaysia healthcare buildings as well as to recommend ways for construction players to design NZEBs in healthcare building in Malaysia.

\subsection{Literature Review}

The purpose of this section is to review the green progress in Malaysia as well as healthcare project progress in Malaysia. This section will also review on NZEBs concept. Besides that, current green design practices in Malaysia will be reviewed in this section as it is important to be clear and understand for this paper.

\subsection{Green and Sustainability Progress in Malaysia}

The Malaysian government has demonstrated their commitment towards achieving sustainable development goals by planning and setting their goals through several national energy policies and the five-year Malaysian plan. For instance, under the recent Eleventh Malaysia Plan (2016-2020), the Malaysian government has set 4 focus area which are strengthening the enabling environment for green growth, adopting the sustainable consumption and production concept, conserving natural resources for present and future generations, and strengthening resilience against climate change and natural disasters (Economic Planning Unit, 2015). These focus areas have proved that the Malaysian government is committed to sustainability.

Apart from that, there are several energy policies that have been introduced by the government such as National Green Technology Policy (NGTP) in 2009 where one of the objectives is to ensure sustainable development and conserve the environment for future generations. Besides that, the New Energy Policy 2010, as embedded in Ninth Malaysia Plan (2006- 2010) has been 
introduced by the Malaysian government which includes economic efficiency, environmental, and social considerations while conserving existing resources (Bohari et al., 2015; Khor et al., 2014). As a regulator, the government's role to improve and enforce sustainable-related regulations will bring changes at the national level.

\subsection{Healthcare Project Progress in Malaysia}

In general, the allocation for Ministry of Health $(\mathrm{MoH})$ health expenditure which involve recurrent and development in Malaysia shows a positive trend where RM3,815 million were allocated by the federal government to $\mathrm{MoH}$ in 1997 to RM23,064 million in 2015 (Ministry of Health Malaysia, 2017). Concerning this trend, MoH health expenditure shows an almost seven-fold increase over eighteen years. Even though for the last three years which are from 2013-3015, the allocation for development budget for $\mathrm{MoH}$ is below 10 percent, but the allocation had always been above 10 percent from 1997 to 2015, as illustrated in Table $\mathbf{1}$.

Table 1: Ministry of Health (MOH) Recurrent and Development Allocation, 1997-2015.

\begin{tabular}{cccccccc}
\hline Year & \multicolumn{2}{c}{$\begin{array}{c}\text { Recurrent } \\
\text { Allocation }\end{array}$} & \multicolumn{2}{c}{$\begin{array}{c}\text { Development } \\
\text { Allocation }\end{array}$} & $\begin{array}{c}\text { Total } \\
\text { Allocation }\end{array}$ & $\begin{array}{c}\text { Increase in Total } \\
\text { Allocation }\end{array}$ \\
\cline { 2 - 9 } & $\begin{array}{c}\text { RM } \\
\text { Million }\end{array}$ & $\begin{array}{c}\text { Per cent } \\
\text { \% }\end{array}$ & $\begin{array}{c}\text { RM } \\
\text { Million }\end{array}$ & $\begin{array}{c}\text { Per cent } \\
\text { \% }\end{array}$ & $\begin{array}{c}\text { RM } \\
\text { Million }\end{array}$ & $\begin{array}{c}\text { RM } \\
\text { Million }\end{array}$ & $\begin{array}{c}\text { Per cent } \\
\text { \% }\end{array}$ \\
\hline 1997 & 3,236 & 84.83 & 579 & 15.17 & 3,815 & - & - \\
\hline 1998 & 3,359 & 82.09 & 733 & 17.91 & 4,092 & 278 & 7.28 \\
\hline 1999 & 3,612 & 80.05 & 900 & 19.95 & 4,512 & 420 & 10.26 \\
\hline 2000 & 4,214 & 76.56 & 1,290 & 23.44 & 5,504 & 991 & 21.97 \\
\hline 2001 & 4,631 & 75.53 & 1,500 & 24.47 & 6,131 & 627 & 11.40 \\
\hline 2002 & 5,139 & 74.98 & 1,715 & 25.02 & 6,855 & 724 & 11.80 \\
\hline 2003 & 5,139 & 74.41 & 1,990 & 25.59 & 7,776 & 921 & 13.44 \\
\hline 2004 & 7,026 & 72.67 & 2,643 & 27.33 & 9,669 & 1,893 & 24.34 \\
\hline 2005 & 7,302 & 85.92 & 1,197 & 14.08 & 8,499 & 1,170 & 12.10 \\
\hline 2006 & 8,206 & 86.35 & 1,297 & 13.65 & 9,503 & 1,004 & 11.81 \\
\hline 2007 & 9,572 & 85.46 & 1,629 & 14.54 & 11,201 & 1,698 & 17.87 \\
\hline 2008 & 10,880 & 83.04 & 2,222 & 16.96 & 13,102 & 1,901 & 16.98 \\
\hline 2009 & 11,863 & 82.21 & 2,567 & 17.79 & 14,430 & 1,328 & 10.14 \\
\hline 2010 & 11,765 & 76.65 & 3,584 & 23.35 & 15,349 & 919 & 6.37 \\
\hline 2011 & 14,302 & 87.82 & 1,984 & 12.18 & 16,287 & 938 & 6.11 \\
\hline 2012 & 15,151 & 89.00 & 1,873 & 11.00 & 17,023 & 737 & 4.52 \\
\hline 2013 & 17,653 & 90.95 & 1,756 & 9.05 & 19,409 & 2,386 & 14.02 \\
\hline 2014 & 20,494 & 93.20 & 1,495 & 6.80 & 21,989 & 2,580 & 13.29 \\
\hline 2015 & 21,714 & 94.15 & 1,350 & 5.85 & 23,064 & 1,075 & 4.89 \\
\hline
\end{tabular}

As a matter of facts, the initial allocation of RM 1.662 billion was allocated by the federal government to $\mathrm{MoH}$ for the development budget has been approved, which includes constructing new hospitals, upgrading existing hospitals, facilities, and others (Ministry of Health Malaysia, 2014). As compared to 2010, there is an increase of 2 new hospitals in 2014 where there are as much as 133 government hospitals and 9 special medical institutions (Ministry of Health Malaysia, 2014). MoH has spent $92.90 \%$ of the adjusted development budget allocation, or equivalent to RM 1.389 billion which comprised of 71 new MoH programs. Based on 71 new MoH programs, it is involved in 67 physical projects and 4 non-physical projects (Ministry of Health Malaysia, 2014). Moreover, for the physical projects, Public Works Department (JKR) will handle 53 projects while JKR Sabah and JKR Sarawak will handle 4 projects and 3 projects respectively. The remaining 4 projects will be handled by the Engineering Services Division (ESD) of MoH (Ministry of Health Malaysia, 2014). 
Based on the statistics, it is understood that the healthcare buildings development in Malaysia is keeping increase over time. Therefore, healthcare buildings sustainability is significant to be considered in the long term. Some of the challenges need to be addressed to ensure that the goals and targets on sustainability that have been planned by the government can be achieved. Besides that, the healthcare industry transformation towards a more sustainable and effective health system in ensuring widespread access to healthcare are possible to be accomplished.

\subsection{NZEBS concept}

NZEBs concept as according to the study of Sartori, Napolitano \& Voss (2012), is a concept where there is a balance between weighted supply and weighted demand. To simplify, the sum of all generated energy and all delivered energy is equal. As showed in Figure 1, the graph displayed that the energy efficiency is also one of an important factor to be considered in NZEBs. Concerning the pathway to NZEB is given by the balance of energy efficiency and energy supply, hence the criteria on energy efficiency and energy supply are important towards NZEBs definition (Sartori, Napolitano \& Voss, 2012). In the same way, Buildings Performance Institute Europe (BPIE) in its reports entitled "Implementing Nearly Zero-Energy Buildings (NZEB) In Poland - Towards A Definition and Roadmap", BPIE specified that the government of Poland is required supporting the energy efficiency measure to successfully implementing NZEBs (Buildings Performance Institute Europe, 2015). Hence, it shows that energy efficiency measure has a significant part in NZEBs and this measure should not be overlooked.

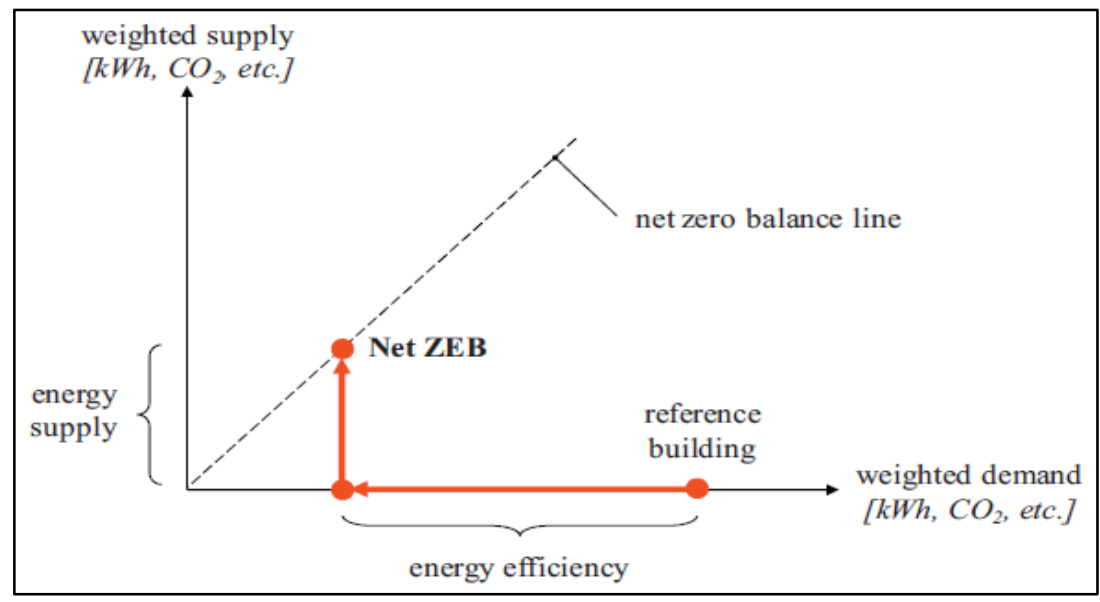

Figure 1: Graph represents the balance concept of NZEBs.

Source: (Sartori et al., 2012)

Thus, based on the developed NZEBs definition, NZEBs is a concept where buildings are utilised renewable energy technologies and the total energy generation from these technologies is equal to the total energy consumption of buildings over the course of a year. Other than that, NZEBs are represented as buildings with high energy performance and are optimally efficient.

\subsection{Current Green Design Practices for Healthcare Buildings in Malaysia}

Integration of green design practices into healthcare buildings is crucial since little attention has been paid on greening the healthcare buildings rather than any other commercial buildings. At present, only a few private healthcare buildings have been assessed by using the Green Building Index (GBI) rating system such as the Amanjaya Specialist Center that scored 'silver' rating, KPJ Ampang Puteri Specialist Hospital that scored 'certified' rating, Gleneagles Hospital that scored 'gold' rating and Columbia Hospital, Petaling Jaya that scored 'certified' rating (Green Building Index, 2018). Even though the green healthcare buildings in Malaysia is still limited, but it is understood that to 
achieve the 'green' certification for healthcare buildings in Malaysia, those buildings should achieve all the criteria as required in GBI rating system.

GBI is Malaysia's first comprehensive environmental rating system for buildings that evaluates the buildings based on the six main criteria such as Energy Efficiency, Indoor Environment Quality, Sustainable Site Planning and Management, Materials and Resources, Water Efficiency, and Innovation. This rating tool was developed by Pertubuhan Akitek Malaysia (PAM) and the Association of Consulting Engineers Malaysia (ACEM), and the tools were derived from the Singapore Green Mark, the Australian Green Star system as well as the existing rating tools to ensure the tools are practical to be used in Malaysia (Green Building Index, 2015). Besides that, GBI is a tool that can be used to evaluates the new construction buildings and existing buildings.

In regard to the healthcare buildings, there are two different types of GBI tools that are available to evaluate the buildings which are non-residential new construction (NRNC) and nonresidential existing buildings (NREB). GBI NRNC tool will be used for the new construction of healthcare buildings while GBI NREB tool is using to assess the existing healthcare buildings. In general, the assessment elements in NRNC and NREB tools are similar. However, the points allocated for each element is slightly different as shown in Table 2.

Table 2: The rating system for healthcare building in Malaysia

\begin{tabular}{lll}
\hline Title & Version / Year & Elements and Points \\
& & \\
\hline GBI NRNC & Version 1.0/ 2015 & Energy Efficiency (EE): 35 \\
& & Indoor Environmental Quality (EQ): 21 \\
& Sustainable Site Planning \& Management (SM): 16 \\
& Material \& Resources (MR): 11 \\
& Water Efficiency (WE): 10 \\
& & Innovation (IN): 7 \\
\hline GBI NREB & Version 1.0/2015 & Energy Efficiency (EE): 38 \\
& & Indoor Environmental Quality (EQ): 21 \\
& & Sustainable Site Planning \& Management (SM): 10 \\
& Material \& Resources (MR): 9 \\
& & Water Efficiency (WE): 12 \\
& & Innovation (IN): 10 \\
\hline
\end{tabular}

By addressing the elements in GBI rating tools, healthcare buildings will be assessed thoroughly and one of key focus to design green healthcare buildings is to consider the energy required for the buildings. Maximizing the amount of natural daylight into a building could reduce the amount of energy requires for artificial lighting in a building (Aksamija, 2015). Besides that, it is important to control passive design strategies in a building as this approach will influence the energy performance of a building such as natural lighting, heat gain, shading, and envelope conduction. (Habash et al., 2014; Omrany \& Marsono, 2016). This view is further supported by Aelenei et al.,(2013), that the passive design strategies in buildings should be appropriately orientating building towards solar heating maximization when buildings are dealing with heating challenges.

Additionally, green healthcare buildings facilitate an integrated choice of building's mechanical and electrical systems. For instance, many research has demonstrated that by implementing different energy efficiency measures in a building, the variation of energy savings can be achieved. According to Marshall et al., (2016) that carried out an investigation of the effectiveness of energy efficiency measures for different occupancy patterns. The authors concluded that similar savings to passive approach and conversion devices can be achieved through the combinations of less expensive and less invasive energy efficiency measures. As a result, these energy efficiency measures options should be greatly promoted. 
Furthermore, integration of renewable energy system into green healthcare buildings is crucial in reducing the demand for a non-renewable energy source. For instance, Phuangpornpitak \& Tia (2013) studying the integration of renewable energy in a smart grid system and they concluded that renewable energy system is one of incomparable option to generate energy since these systems able to provide a clean energy resource. However, they suggested that some issues such as the design, sizing, and the suitability of the system in terms cost for energy generation need to be addressed to ensure that it can be used thoroughly and commercially.

Therefore, to obtain the 'green' certification for healthcare buildings, these buildings should be designed with the integration of renewable energy share as well as utilising energy-efficient technologies so that the energy required to operate this building can be reduced.

\subsection{Research Methodology}

The purpose of this section is to describe the methods that were used for this paper. The semi-structured interviews were employed in this paper and respondents comprises of architects were interviewed to explore the current green design practices for healthcare buildings in Malaysia that have been carried out as well as their understanding on NZEBs. The summary data gathering process is illustrated in Figure 2.

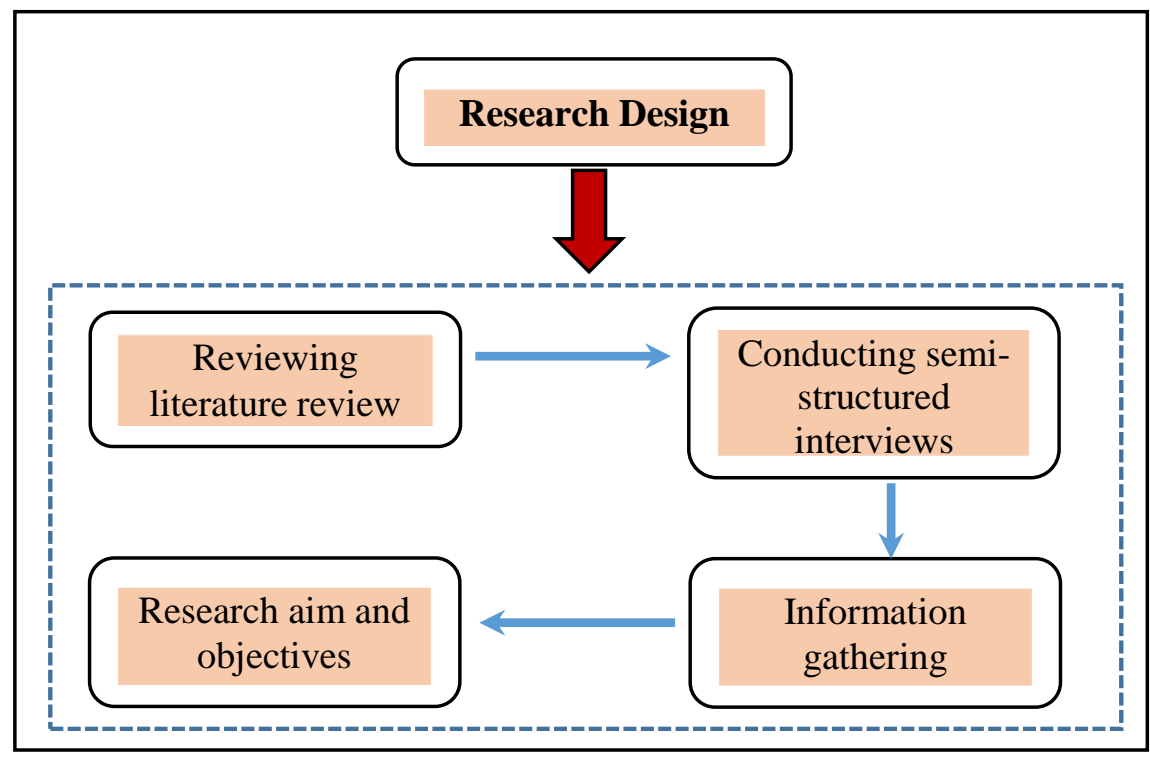

Figure 2: Data gathering process

\subsection{Interview Data Collection Procedure}

A semi-structured interview was chosen for this study since there is a limited literature on the current green design practices for healthcare buildings in Malaysia as well as NZEBs application in Malaysia. Therefore, the focus of these interviews is given to getting an understanding of the green design for healthcare buildings that been practiced in the Malaysian construction industry. In addition, the interview sessions that have been conducted are important to ensure that all current green design practices for healthcare buildings in Malaysia are captured, despite simply relying on the literature. Moreover, the "face-to-face" method of interviews will be undertaken for this study. The selections of places for interviews was decided by interviewees, and each interview took approximately 30 to 60 minutes to complete.

Furthermore, the interviewees were assigned codes as R1, R2, and R3. Besides that, to ensure the quality of the interviews, all respondents are required to be active in the Malaysian construction 
industry and had direct involvement in the buildings projects located within Malaysia. The key profiles for the interviewees are shown in Table 3.

Table 3: Key profiles for interviewees

\begin{tabular}{llll}
\hline Item & R1 & R2 & R3 \\
\hline Position & Architect & Architect & Architect \\
Organization & Consultant & Consultant & Developer / Client \\
Experience & More than 5 years & More than 5 years & More than 5 years \\
\hline
\end{tabular}

As for the interviews, the objective of this paper will be involved to acquire the architect's views on the current green design practices for healthcare buildings in Malaysia as well as their ideas on NZEBs application in Malaysia.

\subsection{Findings and Discussion}

Generally, the interviews results have showed that green design practices for healthcare buildings in Malaysia emphasizes several numbers of features which involve reducing energy use, improving buildings facades, the selection of buildings materials, utilisation of passive solar heating and cooling, the utilisation of energy efficiencies systems as well as renewable energy share in the buildings. These practices have some common with NZEBs design practices even though there are still no specific design strategies in achieving NZEBs design, but based on Yuehong et al., (2015) there are several common design elements and some consensus in designing NZEBs.

According to Aelenei et al., (2012) and Lu et al., (2015), there are three main steps of a design approach that can be applied in designing NZEBs which are the first design approach is a passive approach that focused on reducing energy demand. The second design approach is the use energy efficiency system, and the third design approach is a renewable energy system which is needed to generate renewable energy as well as to offset in large measure the energy demand. The combination of this three-design approach is also crucial to be taken in designing healthcare buildings since these approaches able to succeed in reaching the desired energy performance as well as NZEBs target.

The results of this study indicate that passive approaches are one of the significant element in designing green healthcare buildings in Malaysia since this approach will affect directly the energy needs for the buildings. By gaining a direct solar heat especially in Malaysia, the occupants will feel uncomfortable and it is important for an architect to properly orientated a building so that some areas will be avoided by direct solar radiation (R2). These findings further support the study of Scognamiglio et al., (2014) highlighted that the passive approach plays a significant part in the NZEBs design. Besides that, the improvement of energy consumption of a building can be achieved through passive design strategies as buildings are constructed that react to the environment, hence it is possible for a building to achieve high environmental quality (Hootman, 2012).

Furthermore, some of the interviewees have highlighted that an architect is responsible to ensure some elements of passive approach should be carried out to support the sustainability in construction. These results match those observed in earlier studies such as Habash et al., (2014) stated that architects have an important role in controlling aspects of a passive design when designing NZEBs. Interviewee R1 and R2 have responded that

When designing a healthcare building, an architect is compulsory to follow the standard specification and requirements that have been set by the government. However, an architect can propose some sustainable materials to be applied when designing the healthcare buildings. (R1)

For design and build projects, an architect is encouraged to apply some sustainable elements into passive approaches such as materials selections and a number of ventilation for the buildings. (R2) 
Moreover, according to Thalfeldt et al., (2013) when designing NZEBs, façades have a strong impact on heating, cooling and artificial light in the building needs as well as on daylight. Thus, it is important to realise that the passive heating solutions are essential to be studied along with passive cooling solutions to prevent overheating in a building (Aelenei et al., 2013). Therefore, it is important to consider the passive approach while designing green healthcare buildings as the amount need of artificial light in the building needs will be reduced, hence it will create a pleasant environment.

In regard to the utilisations of energy efficiency system, the interviewees have emphasized that the pathway towards green healthcare buildings is by considering energy efficiency measures. Besides that, energy efficiency has a significant part to act as a parameter that indicates the reduction level of energy consumption in carrying out a related task (Parameshwaran et al., 2012). Generally, energy efficiency can be improved by several design strategies including airtightness to avoid infiltration and mechanical ventilation systems with heat recovery to provide air conditioning and indoor air quality (IAQ) (Barbolini, Cappellacci \& Guardigli, 2017). The R1 interviewee has indicated the importance of energy efficiency system in healthcare buildings

As an architect, we have emphasized the importance of energy efficiency measure for this healthcare building since this measure is much easier to be applied rather than the passive approaches and these measures do not relates to any hygienic condition requirements. (R1)

Moreover, in relation to the availability of energy efficiency technologies in Malaysia, there are no problems to obtain the technologies since Malaysia is one of developing countries (R2, R3). However, the cost for these technologies is quite high and for that reason, most of the developers are not fully utilised the application of energy efficiency technologies in buildings (R3). Similarly, based on Vogel et al., (2015) which investigated barriers that prevent energy efficiency adoption in multifamily buildings in Sweden and authors proposed a novel categorization framework for barriers to energy efficiency in buildings. The results showed that barriers related to contextual level are the most significant to prevent energy efficiency adoption. The contextual level is characterized as the rules and regulations that influence technological design and market development.

Thus, based on the findings and the arguments, energy efficiency measure in a building is vital towards designing a green healthcare building in Malaysia since energy savings in buildings can be achieved. Moreover, by improving the energy efficiency of the various incorporated building systems, it will help to reduce building's energy demand (Sartori, Napolitano \& Voss, 2012).

Additionally, the utilisation of renewable energy share in the buildings is also important towards designing green healthcare buildings in Malaysia. These results are similar with NZEBs design approached since the necessity of renewable energy systems is vital towards NZEBs to reduce and as well as to offset the thermal energy need in buildings. NZEBs should also be designed with the balances energy requirements between active energy production techniques and renewable technologies to achieve the NZEBs objective (Kolokotsa et al., 2011). For designing a green healthcare building, it is important to consider renewable technologies as part of the building since the utilization of renewable energy systems in buildings can be a critical need and solutions against global warming and environmental pollution (Koo et al., 2013).

As a result, since renewable energy system is crucial towards green healthcare building and there is a lot of benefits that can be gained through these systems, the renewable energy systems should be utilised properly when designing a healthcare building. Therefore, through the application of renewable energy technologies to support green healthcare building, is able to reduce the dependency on non-renewable energy and thus, a greener environment can be achieved. The Summary of NZEBs practices and benefits from semi-structured interviews are shown in Table 4. 
Table 4: Summary of current green design practices for healthcare buildings in Malaysia

\begin{tabular}{|c|c|c|c|c|c|}
\hline $\begin{array}{l}\text { Green design } \\
\text { practices }\end{array}$ & $\begin{array}{l}\text { Key points from } \\
\text { interviewees }\end{array}$ & R1 & $\mathbf{R 2}$ & R3 & $\begin{array}{l}\text { The similarity with NZEBs } \\
\text { design practices }\end{array}$ \\
\hline Passive approaches & $\begin{array}{l}\text { Sustainable Materials } \\
\text { Buildings Orientation } \\
\text { Shading Devices } \\
\text { Buildings Ventilation } \\
\text { Daylighting } \\
\text { Thermal Insulation }\end{array}$ & $\begin{array}{l}\sqrt{ } \\
\sqrt{ } \\
\sqrt{ } \\
\sqrt{ } \\
\sqrt{ } \\
-\end{array}$ & $\begin{array}{l}\sqrt{ } \\
\sqrt{ } \\
- \\
\sqrt{ } \\
\sqrt{ } \\
-\end{array}$ & $\begin{array}{l}- \\
\sqrt{ } \\
\sqrt{ } \\
\sqrt{ } \\
\sqrt{ } \\
\sqrt{ }\end{array}$ & $\begin{array}{l}\text { Ferrara et al. (2015); } \\
\text { Ascione et al. (2016a); } \\
\text { Becchio et al. (2015); } \\
\text { Rodriguez-Ubinas et al. } \\
\text { (2014); } \\
\text { Fausto et al. (2017) }\end{array}$ \\
\hline $\begin{array}{l}\text { Energy efficiency } \\
\text { technologies }\end{array}$ & $\begin{array}{l}\text { LED Lightings } \\
\text { Lighting Automation } \\
\text { Energy Star Appliances }\end{array}$ & $\begin{array}{l}\sqrt{ } \\
- \\
\sqrt{ }\end{array}$ & $\begin{array}{l}\sqrt{ } \\
\sqrt{ } \\
\sqrt{ }\end{array}$ & $\begin{array}{l}\sqrt{ } \\
- \\
\sqrt{ }\end{array}$ & $\begin{array}{l}\text { Gaitani et al. (2015); } \\
\text { Dalla et al. (2015); } \\
\text { Buonomano et al. (2015a); } \\
\text { Ascione et al. (2016b) }\end{array}$ \\
\hline $\begin{array}{l}\text { Renewable energy } \\
\text { systems }\end{array}$ & PV Systems & $\sqrt{ }$ & $\sqrt{ }$ & $\sqrt{ }$ & $\begin{array}{l}\text { Kurnitski et al. (2011); } \\
\text { Becchio et al. (2015); } \\
\text { Tian et al. (2015): } \\
\text { Mohamed et al. (2014); } \\
\text { Aksamija (2015) }\end{array}$ \\
\hline
\end{tabular}

\subsection{Conclusion and Recommendation}

The present study was designed to explore the current green design practices for healthcare buildings in Malaysia towards NZEBs. This study is important to support the government initiative to transform the construction industry to be environmental sustainability as stated in Construction Industry Transformation Programme (CITP) 2016-2020. This study showed that the current green design practices for healthcare buildings in Malaysia involve three main design practices which are passive approaches, energy efficiency technologies, and renewable energy systems. Besides that, one of the more significant findings to emerge from this study is that some of the current green design practices for healthcare buildings in Malaysia are common with NZEBs design practices. Although NZEBs concept in Malaysian construction industry is still considered new and it needs to be explored, but some of the green practices that have been carried out in the Malaysia construction industry are able to be applied in the NZEBs concept. The present study makes several noteworthy contributions to the construction players to design NZEBs healthcare buildings in Malaysia in the future. However, it is suggested that other construction players perspective should be included to establish some more comprehensive findings as well as reflect more to the Malaysia context. 


\section{References}

Aelenei D., Aelenei L., Musall E., Cubi E., Ayoub J., \& Belleri A. (2013). Design strategies for non-residential zero-energy buildings: lessons learned from Task40/Annex 52: towards net zero-energy solar buildings. In: CLIMA 2013 - 11th REHVA World Congress \& 8th International Conference on IAQVEC, Book of Proceedings, Prague, Czech Republic, 16-19 June, 2013, 10 p.

Aelenei, L, Ayoub, J., \& Aelenei, D. (2012). Net Zero Energy Residential Building Case Studies. Energy Conservation in Buildings \& Community Systems.

Aksamija, A. (2015). Regenerative Design of Existing Buildings for Net-Zero Energy Use. Procedia Engineering, 118, 72-80.

Anderson, T. R., Hawkins, E., \& Jones, P. D. (2016). CO 2, the greenhouse effect and global warming: from the pioneering work of Arrhenius and Callendar to today's Earth System Models. Endeavour, 40(3), 178-187.

Ascione, F., Bianco, N., De Rossi, F., De Masi, R. F., \& Vanoli, G. P. (2016b). Concept, Design and Energy Performance of a Net Zero-Energy Building in Mediterranean Climate. Procedia Engineering, 169, 26-37.

Ascione, F., De Masi, R. F., de Rossi, F., Ruggiero, S., \& Vanoli, G. P. (2016a). Optimization of building envelope design for nZEBs in Mediterranean climate: Performance analysis of residential case study. Applied Energy, 183, 938-957.

Barbolini, F., Cappellacci, P., \& Guardigli, L. (2017). A Design Strategy to Reach nZEB Standards Integrating Energy Efficiency Measures and Passive Energy Use. Energy Procedia, 111, 205-214.

Becchio C., Bottero M. C., Corgnati S. P., \& Ghiglione C. (2015). nZEB design: challenging between energy and economic targets. Energy Procedia, 78, 2070-2075.

Becchio, C., Dabbene, P., Fabrizio, E., Monetti, V., \& Filippi, M. (2015). Cost optimality assessment of a single family house: Building and technical systems solutions for the nZEB target. Energy and Buildings, 90, 173-187.

Bernama. (2016, October 25). Enam Pesakit Maut Dalam Kebakaran Di ICU Hospital Sultanah Aminah. Bernama. $\quad$ Retrieved $\quad$ March $\quad 19, \quad$ 2018, http://www.bernama.com/bernama/v8/bm/newsindex.php?id=1295493.

Bohari, A. A. M., Skitmore, M., Xia, B., Teo, M., Zhang, X., \& Adham, K. N. (2015). The path towards greening the Malaysian construction industry. Renewable and Sustainable Energy Reviews, 52, 17421748 .

Buildings Performance Institute Europe. (2015). Implementing Nearly Zero-Energy Buildings (NZEB) In Poland - Towards A Definition and Roadmap (Publication). Buildings Performance Institute Europe.

Buonomano, A., Montanaro, U., Palombo, A., \& Vicidomini, M. (2015a). NZEBs in Mediterranean climates: energy design and optimization for a non-residential building. Energy Procedia, 82, 458-464.

Church, J. A., Clark, P. U., Cazenave, A., Gregory, J. M., Jevrejeva, S., Levermann, A., ... \& Payne, A. J. (2013). Climate change 2013: the physical science basis. Contribution of Working Group I to the Fifth Assessment Report of the Intergovernmental Panel on Climate Change. Sea level change, 1137-1216.

Dalla Mora, T., Cappelletti, F., Peron, F., Romagnoni, P., \& Bauman, F. (2015). Retrofit of an historical building toward NZEB. Energy Procedia, 78, 1359-1364.

Economic Planning Unit. (2015). Eleventh Malaysia Plan 2011-2015, Anchoring Growth on People. Putrajaya: Economic Planning Unit.

Ferrara, M., Fabrizio, E., Virgone, J., \& Filippi, M. (2015). Appraising the effect of the primary systems on the cost optimal design of nZEB: A case study in two different climates. Energy Procedia, 78, 2028-2033.

Gaitani, N., Cases, L., Mastrapostoli, E., \& Eliopoulou, E. (2015). Paving the way to nearly zero energy schools in Mediterranean region-ZEMedS project. Energy Procedia, 78, 3348-3353.

Green Building Index. (2015, July). Non-Residential Existing Building (NREB): Hospital. Bangsar, Kuala Lumpur.

Green Building Index. Retrieved April 3 from http://new.greenbuildingindex.org/organisation/building.

Habash, G., Chapotchkine, D., Fisher, P., Rancourt, A., Habash, R., \& Norris, W. (2014). Sustainable Design of a Nearly Zero Energy Building Facilitated by a Smart Microgrid. Journal of Renewable Energy, 2014.

Habash, G., Chapotchkine, D., Fisher, P., Rancourt, A., Habash, R., \& Norris, W. (2014). Sustainable Design of a Nearly Zero Energy Building Facilitated by a Smart Microgrid. Journal of Renewable Energy, 2014.

Hootman T. (2012). Net Zero Energy Design: A Guide for Commercial Architecture, Hoboken, NJ: John Wiley.

Khor, C. S., \& Lalchand, G. (2014). A review on sustainable power generation in Malaysia to 2030: Historical perspective, current assessment, and future strategies. Renewable and Sustainable Energy Reviews, 29, 952-960.

Kolokotsa, D. E. K. D., Rovas, D., Kosmatopoulos, E., \& Kalaitzakis, K. (2011). A roadmap towards intelligent net zero-and positive-energy buildings. Solar Energy, 85(12), 3067-3084. 
Koo C., Hong T., Park H., \& Yun G. (2013). Framework for the analysis of the potential of the rooftop photovoltaic system to achieve the net-zero energy solar buildings. Progress in Photovoltaic: Research and Application, 22(4), 462-478.

Kurnitski, J., Saari, A., Kalamees, T., Vuolle, M., Niemelä, J., \& Tark, T. (2011). Cost optimal and nearly zero (nZEB) energy performance calculations for residential buildings with REHVA definition for nZEB national implementation. Energy and Buildings, 43(11), 3279-3288.

Lee, H. M., Chow, W. K., \& Hung, H. Y. A Study on Residential Fires due to Electrical Faults in Hong Kong. In Proceedings of 3rd Residential Building Design \& Construction Conference - March 2-3, 2016 at Penn State, University Park PHRC.psu.edu.

Lu, Y., Wang, S., \& Shan, K. (2015). Design optimization and optimal control of grid-connected and standalone nearly/net zero energy buildings. Applied Energy, 155, 463-477.

Marshall, E., Steinberger, J. K., Dupont, V., \& Foxon, T. J. (2016). Combining energy efficiency measure approaches and occupancy patterns in building modelling in the UK residential context. Energy and Buildings, 111, 98-108.

Ministry of Health Malaysia. (2014). Annual Report 2014. Putrajaya: Kementerian Kesihatan Malaysia.

Ministry of Health Malaysia. (2017). Malaysia National Health Accounts Health Expenditure Report 19972015. Putrajaya: Kementerian Kesihatan Malaysia.

Mohamed, A., Hasan, A., \& Sirén, K. (2014). Fulfillment of net-zero energy building (NZEB) with four metrics in a single family house with different heating alternatives. Applied Energy, 114, 385-399.

Morgenstern, P., Li, M., Raslan, R., Ruyssevelt, P., \& Wright, A. (2016). Benchmarking acute hospitals: Composite electricity targets based on departmental consumption intensities?. Energy and Buildings, 118, 277-290.

Nawawi, N. M., Sapian, A. R., Majid, N. H. A., \& Aripin, S. (2013). Hospital Design in Tropical Malaysia Towards a Green Agenda. In Proceedings uia/phg 2013 annual healthcare forum + Gupha meeting at IIDEX Canada, Toronto, Canada.

Omrany, H., \& Marsono, A. K. (2016). Optimization of building energy performance through passive design strategies. British Journal of Applied Science \& Technology, 13(6), 1-16.

Parameshwaran R, Kalaiselvam S, Harikrishnan S, \& Elayaperumal A. (2012). Sustainable thermal energy storage technologies for buildings: a review. Renewable Sustainable Energy Reviews, 16(5), 2394-433.

Patiño-Cambeiro, F., Armesto, J., Patiño-Barbeito, F., \& Bastos, G. (2016). Perspectives on Near ZEB Renovation Projects for Residential Buildings: The Spanish Case. Energies, 9(8), 628.

Phuangpornpitak, N., \& Tia, S. (2013). Opportunities and challenges of integrating renewable energy in smart grid system. Energy Procedia, 34, 282-290.

Recast, E. P. B. D. (2010). Directive 2010/31/EU of the European Parliament and of the Council of 19 May 2010 on the energy performance of buildings (recast). Official Journal of the European Union, 18(06), 2010.

Rizalman Hammim. (2016, December 23). Sultanah Aminah Hospital fire caused by capacitor in ceiling lights: Health Ministry. New Straits Times. Retrieved April 14, 2018, from https://www.nst.com.my/news/2016/12/198915/sultanah-aminah-hospital-fire-caused-capacitor-ceilinglights-health-ministry.

Rodriguez-Ubinas, E., Montero, C., Porteros, M., Vega, S., Navarro, I., Castillo-Cagigal, M., ... \& Gutiérrez, A. (2014). Passive design strategies and performance of Net Energy Plus Houses. Energy and buildings, 83, $10-22$.

Sartori, I., Napolitano, A., \& Voss, K. (2012). Net zero energy buildings: A consistent definition framework. Energy and buildings, 48, 220-232.

Scognamiglio, A., Garde, F., \& Røstvik, H. N. (2014). How net zero energy buildings and cities might look like? New challenges for passive design and renewables design. Energy Procedia, 61, 1163-1166.

Thalfeldt M., Pikas E., Kurnitski J., Voll H. (2013). Facade design principles for nearly zero energy buildings in a cold climate. Energy and Buildings, 67, 309-321.

Tian, Z., Zhang, S., Li, H., Jiang, Y., Dong, J., Zhang, B., \& Yi, R. (2015). Investigations of Nearly (net) Zero Energy Residential Buildings in Beijing. Procedia Engineering, 121, 1051-1057.

Torcellini, P., Pless, S., Lobato, C., \& Hootman, T. (2010, May). Main street net-zero energy buildings: the zero energy method in concept and practice. In Proceedings of ASME. International Conference on Energy Sustainability. May. Phoenix, Arizona, USA.

Vogel, J. A., Lundqvist, P., \& Arias, J. (2015). Categorizing barriers to energy efficiency in buildings. Energy Procedia, 75, 2839-2845.

Wang, Y., Mo, S. J., Liang, D., Yang, W. B., Wang, L., \& Zheng, F. J. (2013). Limitation Analysis of Electrical Fire Metallographic Identification Technology. Procedia Engineering, 52, 422-427. 